IZA DP No. 5567

Couple's Relative Labor Supply in Intermarriage

Olga Nottmeyer

March 2011 


\title{
Couple's Relative Labor Supply in Intermarriage
}

\author{
Olga Nottmeyer \\ DIW Berlin, \\ Free University Berlin and IZA
}

\section{Discussion Paper No. 5567 \\ March 2011}

\author{
IZA \\ P.O. Box 7240 \\ 53072 Bonn \\ Germany \\ Phone: +49-228-3894-0 \\ Fax: +49-228-3894-180 \\ E-mail: iza@iza.org
}

Any opinions expressed here are those of the author(s) and not those of IZA. Research published in this series may include views on policy, but the institute itself takes no institutional policy positions.

The Institute for the Study of Labor (IZA) in Bonn is a local and virtual international research center and a place of communication between science, politics and business. IZA is an independent nonprofit organization supported by Deutsche Post Foundation. The center is associated with the University of Bonn and offers a stimulating research environment through its international network, workshops and conferences, data service, project support, research visits and doctoral program. IZA engages in (i) original and internationally competitive research in all fields of labor economics, (ii) development of policy concepts, and (iii) dissemination of research results and concepts to the interested public.

IZA Discussion Papers often represent preliminary work and are circulated to encourage discussion. Citation of such a paper should account for its provisional character. A revised version may be available directly from the author. 


\section{ABSTRACT}

\section{Couple's Relative Labor Supply in Intermarriage*}

In this paper the hypothesis that partnerships between immigrants and natives are less specialized - in the sense that spouses provide similar working hours per weekday - than those between immigrants is tested. The empirical analysis relies on panel data using a twolimit random effects tobit framework to identify determinants of a gender-neutral specialization index. Results indicate that for immigrants intermarriage is indeed related to less specialization as is better education and smaller diversion in education between spouses. In contrast, children living in the household, as well as being Muslim or Islamic, lead to greater specialization. Intermarried immigrants specialize less presumably due to smaller comparative advantages resulting from positive assortative mating by education and different bargaining positions within the household. Natives, on the other hand, show different patterns: for them the likelihood to specialize increases with intermarriage. This might also results from differences in bargaining strength or be due to adaptation to immigrants' expected behavior.

JEL Classification: J1, J12

Keywords: migration, integration, intermarriage, specialization, division of labor

Corresponding author:

Olga Nottmeyer

DIW Berlin

Mohrenstr. 58

10117 Berlin

Germany

E-mail: onottmeyer@diw.de

\footnotetext{
* I am grateful for insightful comments and helpful suggestions by Silke Anger, Tanika Chakraborty, Matthias Schonlau and Klaus F. Zimmermann. This paper contributes to the project on Ethnic Diversity and Labor Market Success in the DFG-Priority Program Flexibility in Heterogeneous Labor Markets (Flexibilisierungspotenziale bei heterogenen Arbeitsmärkten).
} 


\section{Introduction}

Marriages between immigrants and natives, here termed 'intermarriage', is often viewed as indicator of social proximity and possibly a driving factor of individual economic success. Being intermarried seems to signal greater commitment and better integration in the host country. On average, intermarried immigrants tend to have better education, are more likely to work in high-qualified jobs as well as earn more than singles and immigrants who live with other immigrants.

The literature predominately focuses on patterns and determinants of intermarriage. Accordingly, structural characteristics of the marriage market, such as availability of potential partners within the own ethnic group, interference of third parties, personal characteristics including age at immigration, years elapsed in the country and, most prominent, education are among the most important factors.

Starting early in the $21^{\text {st }}$ century, researchers have increasingly focused on intermarriages' potential effects on economic outcomes. Thus, intermarriage is related to economic success in terms of immigrants' wages in the United States, Australia, and France, as well as to employment and self-employment rates of U.S. immigrants. ${ }^{1}$ However, little is known about what happens within the household and in particular how intermarried couples differ from immigrant and native couples with respect to the division of labor. ${ }^{2}$

The aim of this paper is to fill this gap by analyzing differences in relative labor supply of intermarried couples in comparison to immigrant and native couples, and testing whether they coincide with differences in partners' self-assessed bargaining power. In particular, the hypothesis whether intermarried couples are less specialized than immigrant or native couples is tested. This could be due to (a) smaller comparative advantages induced by positive assortative mating by education which leads to more similar education and productivity levels of partners, and/or due to (b) differences in partners' perceived bargaining position as proxied by one's influence on financial and income decisions.

The decision on how much to work relative to the partner depends, among

\footnotetext{
${ }^{1}$ For the United States see Kantarevic (2004), for Australia Meng and Gregory (2005), and for France Meng and Meurs (2009). Dribe and Lundh (2008) and Gevrek (2009) address similar questions regarding immigrants in Sweden and the Netherlands, whereas Furtado and Theodopoulos (2009a) and (2007b), and Georgarakos and Tatsiramos (2009) consider employment and self-employment rates of U.S. immigrants.

${ }^{2}$ Some studies, for instance by Basilio, Bauer, and Sinning (2009) and other studies cited therein, investigate the labor market behavior of immigrants in a family context with particular interest in the so-called "family investment hypothesis".
} 
other factors, on the expected gains from specialization and the bargaining strength of each spouse. If expected gains are low, less specialization is optimal. Plus, if bargaining strength is high more labor supply is expected, where if bargaining position is weak, fewer labor market hours are provided.

Comparing years of schooling, similarities in education, and other personal characteristics such as the so-called 'big five' personality traits indicates that immigrants in intermarriage differ from those in immigrant partnerships. Differences in self-reported bargaining power regarding financial decisions also become apparent.

The empirical analysis builds on panel data from the German SocioEconomic Panel (SOEP), which offer the possibility to incorporate unobserved, time-invariant factors and various individual's and couple's characteristics. ${ }^{3}$ A two-limit random effects Tobit model is used to account for corner solutions in the couple's maximization problem. To allow for possible endogeneity between intermarriage and relative labor supply, the functional form assumptions of the Tobit model are successively relaxed, leading to an instrumental variable estimation. In that an ethnicity-gender ratio similar to those proposed in previous studies is used as identifying restriction. The analysis considers cohabiting couples and proposes a gender-neutral specialization index to measure to what extent one partner contributes to the mass of couple's working hours. ${ }^{4}$

Empirical findings indicate that intermarriage is, indeed, highly related to less specialization especially for immigrant men. For immigrant women this relation also holds but is somewhat weaker. In contrast, natives in intermarriage seem to specialize even more if intermarried than in partnerships with natives. This finding might indicate that natives' view on female labor force participation differs from that of immigrants, and intermarried natives adapt to their partners' views in order to mitigate conflict potential within the partnership. In addition, bargaining power of the native partner, especially the wife, might be better in intermarriage due to better and more similar education, better outside options and different threat points. ${ }^{5}$

\footnotetext{
${ }^{3}$ For further information about this data source see for example Wagner, Frick and Schupp (2007).

${ }^{4}$ This approach is motivated by work by Stratton (2005) and Bonke et al. (2008) who use a similar design to detect differences in the degree of specialization in household tasks between married and cohabiting couples, and between couples in the United States and Denmark respectively.

${ }^{5}$ This relates to arguments given in models of collective labor supply where bargaining strength depends on partners' threat points and their outside options. For more information about collective labor supply models, its assumptions, tests, and implications see for instance: Klaveren et al. (2009); Blundell et al. (2007); Attanasio and Lechene (2002); Chiappori, Fortin, and Lacroix (2002) ; Lundberg and Pollak (1996); Chiappori (1988).
} 
According to self-reported bargaining strength, intermarried immigrant men are less likely to be the sole decision maker in the household, whereas in immigrant households financial decisions are mostly made by the husband. For natives and immigrant women no such differences are found depending on the origin of the spouse.

In the next section various concepts related to intermarriage are discussed. In addition, a brief sketch of the theory behind intra-household division of labor is given. Section 3 then explains the construction of the specialization index, followed by a summary of definitions and the data description in Section 4. In Section 5 the empirical results are presented and discussed including a subsection that contains some robustness checks. The paper concludes with a summary of results and an outlook for further research.

\section{Background}

\subsection{Determinants of Intermarriage and Its Economic Implications}

Previous research regarding intermarriage primarily focused on patterns and determinants of intermarriage, that is factors that increase the likelihood to marry outside the own ethnic group and, in particular, for immigrants to marry native partners. This strand of literature predominately evolved in traditional immigration countries such as the United States and Australia, but is also increasingly prominent in Germany and other European countries like France, Sweden and the Netherlands.

More recently, studies of economic implications from intermarriage find mostly positive effects from native partners for immigrants. Even though Kantarevic (2004) finds no significant effect of intermarriage on immigrants' earnings in the United States once he controls for possible endogeneity, Meng and Gregory (2005) and Meng and Meurs (2009) do find positive influences on earnings for Australian and French immigrants. They account for selection into intermarriage by using an instrumental variable approach that serves as the model for the instrument used in this paper. Furtado and Theodoropoulos (2009a) and (2009b), as well as Georgarakos and Tatsiramos (2009) use different productivity measures, namely employment status and self-employment probabilities, also finding positive effects for U.S. immigrants. Until now, little is known about such relations for immigrants in Germany.

Among the most important factors driving marriage choice are structural constraints in the marriage market such as gender ratios and the availability 
of partners within the own ethnic community (Angrist (2002)). Additionally, interference of third parties (mainly parents), religious beliefs, socio-economic status, and cultural and linguistic proximity determine the decision of whom to marry. These factors, at least partly, explain why some immigrant groups show a greater tendency toward intermarriage than others. However, individual characteristics and personal preferences must not be neglected. In particular, immigrants are more likely to intermarry if they immigrated at young ages, spent considerable time in the hosting country, exhibit good language skills, and, most importantly, are highly educated (Furtado (2006); Furtado and Theodoropoulos (2010); Chiswick and Houseworth (2008)).

Higher education is among the most prominent factors driving intermarriage choice as better educated immigrants are assumed to be less likely to live in ethnic enclaves and to better adapt to a foreign environment. ${ }^{6}$ Furthermore, intermarried immigrants are more receptive to 'positive assortative mating by education' according to which people match predominately based on similarities in education. ${ }^{7}$ According to Becker (1974), people generally match based on similar bundles of resources. However, partners do not need to be identical in each characteristic but can compensate for differences in one property by offering greater harmony in other areas. Hence, partners with heterogeneous ethnic backgrounds tend to be more similar with respect to education than couples with the same ethnic background (see Chiswick and Houseworth (2008); Furtado (2006); Furtado and Theodoropoulos (2010)). Moreover, educational institutions usually serve as social platform for meeting potential future spouses.

\subsection{Couple's Specialization}

The degree of specialization depends, among others, on expected gains and associated costs from the division of labor within the household. Based on Becker (1981) and discussed for instance by Bonke et al. (2008), specialization and the division of labor are "fundamental principles of economics and allow for production at lowest possible costs". This principle creates an advantage of multi person over single person households and results in household specialization to the extent that one partner focuses mainly on labor market work whereas the other specializes in home production.

\footnotetext{
${ }^{6}$ For a detailed discussion of these effects see Furtado (2006) and Furtado and Theodoropoulos (2010).

${ }^{7}$ Positive assortative mating, that is positive correlation between values of traits of husbands and wives, also applies to IQ, height, attractiveness, skin color, and ethnic origin. According to Becker (1985), there is no positive assortative mating by earnings. However, this finding is discussed controversially in the literature.
} 
Who specializes in which tasks thereby depends on different aspects such as resource endowment, time availability, ideology and egalitarian views. Accordingly, members with the most power will do less housework (Hersch and Stratton (1994)) - thereby 'power' can be related to comparative advantages and better outside options. Hence, those with higher expected earnings, and therefore higher opportunity costs, will contribute more time to labor market work. In addition, the least time constrained party will do the house work whereas the more time constraint partner specializes in labor work. Furthermore, ideology and the importance of individual beliefs regarding gender roles - keyword: doing gender - also play an important role in the division of labor (Bittman, England, and Folbre (2003)). Consequently, couples with more egalitarian views - mainly younger, more liberated people - divide tasks more equally (Fuwa (2004)).

Putting this in a more formal framework and following the arguments given in the context of collective labor supply models, couples' utility can be written as the weighted sum of spouses' individual utilities subject to their time and budget constraints and incorporating home production. Adopting the notation given by Klaveren et al. (2009) the couple's maximization problem then reads as follows:

$$
\begin{array}{r}
\max \quad U_{h}=\pi U_{m}+(1-\pi) U_{f} \\
\text { s.t. } Y=w_{m}\left(T-l e_{m}-w h_{m}\right)+w_{f}\left(T-l e_{f}-w h_{f}\right)+y \\
H=w h_{m}+\gamma w h_{f} ; \\
0<l f_{m}, l f_{m}, w h_{m}, w h_{f} \leq 1 .
\end{array}
$$

$U_{h}$ thereby refers to the household's utility, $U_{m}$ and $U_{f}$ to husbands and wives individual utilities. For $i \in\{m, f\}, l e_{i}$ denotes leisure time, $w h_{i}$ hours worked in the household, $w_{i}$ denotes individual labor earnings, $T$ refers to the total amount of time available, $H$ to household production, and $y$ is non-earned income. Allowing $\gamma$ to diverge from one accounts for different productivities in household production between husbands and wives, and $\pi$ captures differences in bargaining strength between spouses. Thereby $\pi$ captures, for instance, relative resource endowment, time availability, outside options and egalitarian views. The higher $\pi$ the stronger the bargaining position of the husband relative to his wife, and hence the lower the bargaining power of the wife.

It is assumed here that the observed labor supply of each spouse is the optimal solution of this maximization problem given his/her bargain- 
ing strength. According to Klaveren er al. (2009) $\pi$ depends mainly on labor market earnings, the number of children living in the household, the age of the partners, and net weekly non-labor income. However, measuring actual bargaining power is difficult. Thus, Klaveren et al. (2009) rely mainly on functional form assumptions underlying the model. Alternative studies, such as those by Lührmann and Maurer (2009), as well as Beegle, Frankenberg, and Thomas (2001) use self-reported information on who has the final say in household's decisions. A similar variable is used in this study as robustness check to depict different decision patterns in intermarriage and immigrant and native marriages.

Independent of the 'sexual' division of labor within the couple - meaning whether the husband or the wife specializes in household labor -, greater gains from specialization are expected for couples with greater differences in skills and abilities (Becker (1981) and (1985)). In particular, smaller differences in education will lead to less specialization due to smaller expected gains. In addition, the degree of specialization may differ with household characteristics, especially with expected duration of the relationship as proposed by Stratton (2005). The longer the expected period of specialization, the lower the present value of costs from changing tasks when the relationship ends, and the greater the optimal degree of specialization. Consequently, partners should specialize more if they expect the relationship to last longer.

\subsection{Working Hypothesis}

Relating these arguments to intermarriage implies that intermarried couples may be less specialized than immigrant couples for the following reasons:

(1) Intermarried spouses tend to be more similar in education due to assortative mating. Accordingly, intermarried immigrants seem to compensate for differences in ethnicity with greater similarity in education (see Chiswick and Houseworth (2008) for an analysis of U.S. immigrants). This induces similar productivity levels of partners in intermarriage and hence a smaller comparative advantage of one partner over the other. This, in turn, reduces the incentive to specialize and results in less division of labor. In contrast, immigrant couples are, by definition, ethnically homogeneous and hence may place less emphasis on similar education. Hence, a higher comparative advantage of one partner is expected that, among other determinants, will lead to greater specialization within those partnerships.

(2) Bargaining power in intermarriage might be shifted to the native partner due to better labor market options. The native partner is more familiar with the host country's customs, norms, and peculiarities, has a better knowledge of the local labor market, faces less discrimination based 
on ethnicity, and exhibits better host country specific skills requested by native employers.

Adding to that, the native spouse might pressure the immigrant partner if the immigrant's permission of residence depends solely on the marital status and the immigrant is threatened with expulsion in case of divorce. Residential status of immigrants - referring to especially foreigners from non-EU member states - who come to Germany exclusively based on marriage with a German national, depends principally on the duration of that marital union. Intermarried bi-national couples need to spend a considerable time 'living their marriage' before the immigrant spouse receives an autonomous right of residence (eigenständiges Aufenhaltsrecht). Hence, particularly within the first years after immigration, divorce could lead to deportation of the immigrant partner. This, in turn, might affect the distribution of bargaining power within the marriage, spouses' threat points in event of divorce and, therefore, relative labor supply patterns. However, testing this hypothesis is beyond the scope of this paper and is left for future analyses. What can and will be tested with the available data are differences in the self-assessed power over financial decisions between intermarried and ethnically homogeneous couples.

(3) Furthermore, marriage among religious immigrants, in particular Muslims, are often arranged without giving a "de facto" possibility to divorce. Consequently, a higher degree of specialization is expected for immigrant and particularly Muslim couples.

(4) Finally, intermarried couples may be exposed to more conflict potential because of their different cultural background, as discussed by StöckerZafari (2007). As shown by Bratter and Eschbach (2006) intermarriage is also associated with an increase in severe distress for some immigrants in the United States. Hence, intermarriages may be expected to end earlier than ethnically homogeneous marriages, which lowers the incentive to specialize due to higher costs in case of separation. ${ }^{8}$

Native couples may represent either more traditional or more modern concepts of division of labor. On the one hand, because they are homogeneous with respect to ethnicity, spouses might differ more in educational attainment than intermarried couples and thus have similar specialization behavior as do immigrant couples. On the other hand, natives might have more egalitarian views with respect to female labor force participation and hence specialize less. Moreover, getting divorced and re-marry might be more common among natives than it is in the immigrant's country of origin which may

\footnotetext{
${ }^{8}$ see also Kalmijn et al. (2005), who study the relationship between intermarriage and the risk of divorce in the Netherlands.
} 
affect the threat point within the partnership. The degree of specialization in intermarriages can thus differ from or resemble that of native couples.

\section{Measure of the Degree of Specialization}

The variable of interest is the degree of specialization in labor market work measured by the index $S_{i t}$. This index captures whether one partner supplies the bulk of working hours in period $t$. It is normalized between zero and one, with $S_{i t}=0$ referring to equal provision of labor market hours, and $S_{i t}=1$ denoting complete specialization of one partner. Thereby $h_{t}^{i}$ refers to individual $i$ 's average working hours per weekday in period $t$, and $h_{t}^{-i}$ denotes working hours provided in $t$ by $i$ 's partner. $S_{i t}$ is defined as:

$$
S_{i t}:=\left(\frac{\max \left\{h_{t}^{i}, h_{t}^{-i}\right\}}{h_{t}^{i}+h_{t}^{-i}}-\frac{1}{2}\right) \cdot 2 .^{9}
$$

The shortcoming of this index is that it does not allow for differentiation on who specializes - husband or wife - but an increase in $S_{i t}$ clearly indicates more specialization, whereas a decrease in $S_{i t}$ unambiguously indicates more similarity in terms of supplied labor hours. ${ }^{10}$ However, in the majority of cases observed in the data, husbands provide at least as many hours to labor market work as does the wife. Results, therefore, do not change qualitatively when restricting the sample to those cases and can hence be interpreted in the sense that $S_{i t}=1$ refers to cases when the husband is the single breadwinner in the household.

The German Socio-Economic Panel (SOEP) gives information about hours spent on labor market work, household work, child care, repairs and other activitie including hobbies. The structure of how this information is gathered changes slightly over time. For instance, in the first wave interviewers ask about time allocation during the workweek, that is Monday to Saturday, and on Sundays. Later the distinction is made between Monday to Friday, Saturday, and Sunday - but only for alternating years. For the years in between, only weekly hours (Monday to Friday) are surveyed. ${ }^{11}$ These changes result in slightly different answer schemes and do not allow for direct comparison of working hours in one year with working hours in the subsequent year. To circumvent this problem the index is created such that it does not rely on the absolute but the relative amount of working hours. It is assumed that both

\footnotetext{
${ }^{10}$ In case both partners provide zero working hours the ratio is set to missing.

${ }^{11}$ Furthermore, in 1984, the first year of the panel, zero working hours are not reported.
} 
partners make the same multiplicative adjustment $\epsilon$ to the different question schemes. Thus, in every alternating year the reported value is $h_{t}^{i}(1+\epsilon)$ instead of $h_{t}^{i}$. Using the ratio embedded in equation (1) eliminates such an error because:

$$
\frac{h_{t}^{i}(1+\epsilon)}{h_{t}^{i}(1+\epsilon)+h_{t}^{-i}(1+\epsilon)}=\frac{h_{t}^{i}}{h_{t}^{i}+h_{t}^{-i}} .
$$

However, for even better robustness, estimations are run only for alternating years for which the framing of the questions is identical.

\section{Data}

\subsection{Definitions}

Similar to Becker (1974) and various following studies, "marriage" is defined as sharing the same household. Hence, the underlying sample is restricted to people who report a partner living in the same household. In the final sample about 86 percent of those partnerships refer to formal marriage ("married, living together"). Marriage is put on the level of partnership or cohabitation, and partners are addressed as spouses, husbands and wives even though they might not be formally married.

A partnership between an immigrant and a native is called "intermarriage" even though this definition does not generally include marriage between people with different ethnic origins. ${ }^{12}$ Marital constellations between two immigrants are called 'immigrant marriage'. Note that spouses in immigrant marriages need not come from the same country of origin but both exhibit a migration background. Having a migration background refers to being born outside of Germany, having non-German citizenship, being born to parents who do not hold German citizenship or to parents who were not born in Germany. Marriage between two natives is called "native marriage".

First generation immigrants are defined as people not born in Germany. Those who are born in Germany but (a) do not hold German citizenship, or (b) have at least one parent who is not German-born or of non-German nationality are called second generation immigrants. Both first and second generation immigrants are considered assuming that members of the second generation are not fully assimilated - in the sense of being indistinguishable from natives - and still differ in their behavior, at least partly, from natives. Marriage between first and second generation immigrants is thus treated as

\footnotetext{
${ }^{12}$ The term is used more in the sense of "marriage into the native society"
} 
immigrant marriage, whereas marriage between natives and second generation immigrants is considered intermarriage.

People are considered only when a current partner is observed and when they report non-missing working hours. One person can be observed with different partners. It is thereby assumed that former marriages do not influence future marriages.

\subsection{Sample Construction}

The focus of this study lies on the working age population, hence people aged 20 to 65 . Apart from the age restriction, people are included independent of their working status, that is the analysis includes full and part time employed, as well as occasionally employed people, unemployed and those who are still enrolled in school. ${ }^{13}$

Due to different questioning schemes in alternating years, only every second year is considered. Furthermore, language information and information about the nationality of the best friend, is be used in the descriptive section to highlight different behavior of those who are intermarried, is available exclusively for 1997, 1999, 2001, 2003 and 2005. Hence, these are the years considered in this study. 2005 data additionally have the advantage of containing information about the so-called "big five" personality traits that give insight to one's self-perception with respect to openness, agreeableness, conscientiousness, neuroticism/emotional stability, and extraversion. These traits model the basic structure of all expressions of personality and capture personality differences between individuals as expressed through different modes of behavior and experience. They are used in the fields of psychology and sociology to analyze personality structures. The five factors are constructed out of information about individual communicative ability, agreeableness, originality, imaginativeness, work attitudes, attitudes toward worry and stress, self-restraint, cordiality, as well as the value placed on artistic and aesthetic experiences measured on a self-report basis. A factor analysis of these responses is conducted and the data are then grouped into an aggregate value for each of the five traits. ${ }^{14}$ Moreover, for 2005 information on how income is distributed between spouses and who has the final say in financial decisions

\footnotetext{
${ }^{13}$ For the unemployed reported hours of work are expected to equal zero. Observations of people who give inconsistent answers are set to missing. Consequently, people who report zero weekly working hours while being full-time, part-time or occasionally employed are not considered, as are people who report positive hours of work while being unemployed. People may work while being enrolled in school and are still included in the sample.

${ }^{14}$ For more information about the big five and its construction in the SOEP see Gerlitz and Schupp (2005), or Dehne and Schupp (2007).
} 
is available. This information is used in robustness testing to support the argument that bargaining power is differently distributed in intermarriage than in other marital unions.

\subsection{Statistics}

Tables 1 and 2 show selected characteristics of men and women who live in either intermarriage, immigrant or native partnerships. The numbers refer to two-year observations available between 1997 and 2005. Accordingly, roughly 18 percent of the observations refer to immigrants. Most of the immigrant men originate from Turkey, Italy, Poland, Greece, and states of former Yugoslavia. Immigrant women mainly came from Turkey, Italy, Poland, Russia, and Greece. Immigrants living in Germany predominately immigrated during the 'guest worker' recruitment period of the 1950s to 1970s, the family reunification after the recruitment stop in 1973, as asylum seekers, or as ethnic Germans after the fall of the Iron Curtain. ${ }^{15}$

The share of intermarriage out of the total observed partnerships is relatively low, especially among natives. Only 5.0 percent of native women and 4.7 percent of native men report an immigrant partner. Within the immigrant population this share is considerably higher: 21.9 percent of immigrant women and 22.7 percent of immigrant men report living with a native. This pattern is surly induced not only by preferences but also by group size differences: The bigger the own ethnic group and the more potential partners are available within the own ethnic community, the less likely it becomes to marry somebody from outside that group. Members of the majority population as well as members of big minority groups are thus more likely to marry a partner with the same ethnic background than members of small ethnic groups.

Intermarried native men most often live with women from Poland, Italy, Austria, states formerly belonging to Yugoslavia, Russia, France, the Philippines and Romania. Intermarried native women on the other hand are most likely to be married to men with Italian, Turkish, Spanish, Greek, Yugoslavian or Polish background. ${ }^{16}$ Hence, these men come mainly from countries with more paternalistic family structures compared to Germans which might explain some of the later results.

The majority of immigrant men (63.2 percent of those in intermarriage and 73.2 percent of those in immigrant partnerships) work on average 8 to 10

\footnotetext{
${ }^{15}$ For further information about the historic evolution of immigration to Germany see for instance Kalter and Granato (2007).

${ }^{16}$ For a detailed discussion of different marital patterns among non-German nationals see for instance Gònzalez-Ferrer (2006), Haug (2006) or Schroedter (2006).
} 
Table 1: Selected characteristics of men

Immigrant

Native

\begin{tabular}{|c|c|c|c|c|}
\hline Selected Characteristics & Intermarriage & $\begin{array}{l}\text { Immigrant } \\
\text { Marriage }\end{array}$ & Intermarriage & $\begin{array}{c}\text { Native } \\
\text { Marriage }\end{array}$ \\
\hline Number of Obs. ${ }^{1}$ & \multicolumn{2}{|c|}{ 年,831 (18.1\%) } & \multicolumn{2}{|c|}{ "17,283(81.9\%) } \\
\hline Working hours per Weekday: & $11.4 \%$ & $11.4 \%$ & $10.3 \%$ & $9.3 \%$ \\
\hline $8-10$ & $63.2 \%$ & $73.2 \%$ & $61.3 \%$ & $61.7 \%$ \\
\hline $11-12$ & $17.4 \%$ & $8.9 \%$ & $18.9 \%$ & $19.8 \%$ \\
\hline Marriage Pattern & $\begin{array}{c}869 \\
(22.7 \%)\end{array}$ & $\begin{array}{c}2,962 \\
(77.3 \%)\end{array}$ & $\begin{array}{c}819 \\
(4.7 \%)\end{array}$ & $\begin{array}{c}16,464 \\
(95.3 \%)\end{array}$ \\
\hline Labor Hours & 8.5 & 8.1 & 8.7 & 8.8 \\
\hline Partner's Labor Hours & 5.4 & 3.9 & 4.7 & 5.4 \\
\hline Household Hours & 1.4 & 1.3 & 1.4 & 1.4 \\
\hline Partner's Household Hours & 3.9 & 4.8 & 3.9 & 4.0 \\
\hline Years of Education & 12.1 & 10.5 & 12.6 & 12.7 \\
\hline Difference in Education & 0.0 & 0.3 & 0.3 & 0.3 \\
\hline Age at Marriage & 29.2 & 25.4 & 30.9 & 28.4 \\
\hline Duration of Marriage & 13.2 & 17.6 & 13.7 & 17.3 \\
\hline Years since Immigration & 26.2 & 19.7 & / & / \\
\hline \multirow{2}{*}{\multicolumn{5}{|c|}{ Language $^{2}$ (German): }} \\
\hline & & & & \\
\hline Writing & 2.0 & 2.8 & / & 1 \\
\hline with Germany & \multicolumn{3}{|c|}{ Identity $^{3}$ : } & / \\
\hline with Home Country & 2.5 & 2.5 & / & / \\
\hline \multicolumn{5}{|l|}{ Big Five ${ }^{4}$ : } \\
\hline $\begin{array}{r}\text { Openness } \\
\text { Emotional stability }\end{array}$ & \multicolumn{2}{|c|}{ positive $^{* * *}$} & & \\
\hline $\begin{array}{r}\text { Emotional stabillty } \\
\text { Extraversion }\end{array}$ & \multicolumn{2}{|c|}{ positive $^{* * *}$} & & \\
\hline Agreeableness & \multicolumn{2}{|c|}{ negative ${ }^{* * *}$} & & \\
\hline \multicolumn{5}{|l|}{ Conscientiousness } \\
\hline Risk proclivity ${ }^{5}$ : & 5.0 & 4.3 & 5.2 & 5.1 \\
\hline \multicolumn{5}{|l|}{ Origin of best friend: } \\
\hline East or West Germany & $73.0 \%$ & $32.4 \%$ & $90.7 \%$ & $99.1 \%$ \\
\hline Other country & $27.0 \%$ & $67.6 \%$ & $9.3 \%$ & $0.9 \%$ \\
\hline \multicolumn{5}{|l|}{ Distribution of income: } \\
\hline Each manages money separately & $19.7 \%$ & $3.9 \%$ & $17.6 \%$ & $16.1 \%$ \\
\hline I manage, partner receives portion & $4.8 \%$ & $10.9 \%$ & $8.4 \%$ & $3.8 \%$ \\
\hline Partner manages, I receive portion & $6.1 \%$ & $9.4 \%$ & $4.6 \%$ & $6.7 \%$ \\
\hline All money shared & $59.7 \%$ & $72.9 \%$ & $61.2 \%$ & $63.9 \%$ \\
\hline Part shared, part kept separate & $9.6 \%$ & $2.9 \%$ & $8.2 \%$ & $9.6 \%$ \\
\hline \multicolumn{5}{|l|}{ Final say in financial decisions: } \\
\hline Myself & $9.0 \%$ & $16.6 \%$ & $10.8 \%$ & $7.1 \%$ \\
\hline Partner & $11.3 \%$ & $6.2 \%$ & $5.9 \%$ & $6.1 \%$ \\
\hline Both & $79.7 \%$ & $77.2 \%$ & $83.3 \%$ & $86.8 \%$ \\
\hline
\end{tabular}

Source: German Socio-Economic Panel (SOEP), unbalanced panel, years 1997, 1999, 2001, 2003, 2005

1 Those numbers refer to observations not to individuals, unweighted sample, years 1995 to 2005.

2 Self-reported value measured on a scale frßm 1 (="very good") to 5 (="very poor")

3 Self-reported value measured on a scale from 1 (="strong") to 5 (="poor")

4 Values are conducted from a factor analysis;

positive/negative***: significant differences between those intermarried and those who are not

5 Self-reported value measured on a scale from 1 (="highly risk averse") to 10 (="highly risk loving") 
Table 2: Selected characteristics of women

Immigrant

Native

\begin{tabular}{|c|c|c|c|c|}
\hline Selected Characteristics & Intermarriage & $\begin{array}{l}\text { Immigrant } \\
\text { Marriage }\end{array}$ & Intermarriage & $\begin{array}{c}\text { Native } \\
\text { Marriage }\end{array}$ \\
\hline Number of Obs. ${ }^{1}$ & \multicolumn{2}{|c|}{ (3,976 (18.2\%) } & \multicolumn{2}{|c|}{ "17,833(81.8\%) } \\
\hline Working hours per Weekday: & $34.3 \%$ & $44.7 \%$ & $29.8 \%$ & $27.3 \%$ \\
\hline $8-10$ & $28.6 \%$ & $25.3 \%$ & $34.5 \%$ & $32.5 \%$ \\
\hline $11-12$ & $4.1 \%$ & $1.7 \%$ & $4.8 \%$ & $5.3 \%$ \\
\hline Marriage Pattern & $\begin{array}{c}870 \\
(21.9 \%)\end{array}$ & $\begin{array}{c}3,106 \\
(78.1 \%)\end{array}$ & $\begin{array}{c}893 \\
(5.0 \%)\end{array}$ & $\begin{array}{c}16,490 \\
(95.0 \%)\end{array}$ \\
\hline Labor Hours & 4.5 & 3.7 & 5.2 & 5.2 \\
\hline Partner's Labor Hours & 8.7 & 8.1 & 8.6 & 8.9 \\
\hline Household Hours & 4.0 & 4.9 & 4.0 & 4.0 \\
\hline Partner's Household Hours & 1.4 & 1.2 & 1.4 & 1.4 \\
\hline Years of Education & 12.3 & 10.2 & 12.2 & 12.3 \\
\hline Difference in Education & -0.4 & -0.3 & -0.0 & -0.4 \\
\hline Age at Marriage & 27.9 & 22.4 & 27.8 & 25.9 \\
\hline Duration of Marriage & 13.6 & 18.0 & 13.3 & 17.4 \\
\hline Years since Immigration & 21.9 & 17.9 & / & / \\
\hline \multirow{2}{*}{\multicolumn{5}{|c|}{ Language $^{2}$ (German): }} \\
\hline & & & & \\
\hline Writing & 1.9 & 2.8 & / & 1 \\
\hline with Germany & 2.7 & 3.1 & l & l \\
\hline with Home Country & 2.5 & 2.5 & / & / \\
\hline Big Five ${ }^{4}$ : & & & & \\
\hline $\begin{array}{r}\text { Openness } \\
\text { Emotional stability }\end{array}$ & \multicolumn{2}{|c|}{ positive $^{* * *}$} & & \\
\hline $\begin{array}{r}\text { Emotional stability } \\
\text { Extraversion }\end{array}$ & & & \\
\hline Agreeableness & \multicolumn{2}{|c|}{$\begin{array}{l}\text { positive }^{* * *} \\
\text { negative }\end{array}$} & & \\
\hline \multicolumn{5}{|l|}{ Conscientiousness } \\
\hline Risk proclivity ${ }^{5}$ : & 4.1 & 3.0 & 4.1 & 4.2 \\
\hline \multicolumn{5}{|l|}{ Origin of best friend: } \\
\hline East or West Germany & $70.1 \%$ & $32.4 \%$ & $91.3 \%$ & $98.9 \%$ \\
\hline Other country & $29.9 \%$ & $67.6 \%$ & $8.7 \%$ & $1.1 \%$ \\
\hline \multicolumn{5}{|l|}{ Distribution of income: } \\
\hline Each manages money separately & $17.6 \%$ & $4.1 \%$ & $20.5 \%$ & $16.0 \%$ \\
\hline I manage, partner receives portion & $3.9 \%$ & $9.2 \%$ & $6.8 \%$ & $6.1 \%$ \\
\hline Partner manages, I receive portion & $7.9 \%$ & $11.7 \%$ & $5.5 \%$ & $4.1 \%$ \\
\hline All money shared & $62.5 \%$ & $72.0 \%$ & $59.2 \%$ & $64.2 \%$ \\
\hline Part shared, part kept separate & $8.2 \%$ & $3.0 \%$ & $8.1 \%$ & $9.6 \%$ \\
\hline \multicolumn{5}{|l|}{ Final say in financial decisions: } \\
\hline Myself & $6.0 \%$ & $6.7 \%$ & $9.3 \%$ & $5.5 \%$ \\
\hline Partner & $11.5 \%$ & $16.7 \%$ & $9.3 \%$ & $6.9 \%$ \\
\hline Both & $82.5 \%$ & $76.6 \%$ & $81.3 \%$ & $87.7 \%$ \\
\hline
\end{tabular}

Source: German Socio-Economic Panel (SOEP), unbalanced panel, years 1997, 1999, 2001, 2003, 2005

1 Those numbers refer to observations not to individuals, unweighted sample, years 1995 to 2005.

2 Self-reported value measured on a scale fir $\$$ m 1 (="very good") to 5 (="very poor")

3 Self-reported value measured on a scale from 1 (="strong") to 5 (="poor")

4 Values are conducted from a factor analysis;

positive/negative***: significant differences between those intermarried and those who are not

5 Self-reported value measured on a scale from 1 (="highly risk averse") to 10 (="highly risk loving") 
hours per weekday. 8.9 percent in immigrant marriages and even 17.4 percent in intermarriages work slightly more, namely 11 to 12 hours. Among native men, the share of those working 8 to 10 hours is slightly smaller $(61.3$ percent in intermarriage and 61.7 percent in native marriages). However, a greater share (18.9 percent in intermarriage and 19.8 percent in native partnerships) works 11 to 12 hours. Among native women 27.3 percent in native marriages and 29.3 percent in intermarriage report zero working hours. For immigrant women this share is noticeably bigger, particularly among those who live with another immigrant: 44.7 percent of immigrant women in immigrant marriages do not provide any labor hours. Among the intermarried the share of women reporting zero hours of work is only 34.3 percent which is noticeably closer to the shares of natives. About one fourth (25.3 percent) of women in immigrant marriage and up to one third (28.6 percent of immigrant women in intermarriage, 32.5 percent of women in native marriages and 34.5 percent of intermarried native women) work 8 to 10 hours. Thus, women in intermarriages tend to work more than those in ethnically homogeneous partnerships.

On average, native men in intermarriage do not differ much regarding the presented characteristics from men in native marriages. ${ }^{17}$ Accordingly, natives show no significant differences by type of marriage with respect to their average labor hours, partner's labor hours, and hours spend on household tasks - neither by themselves nor by their partners. There is no difference in education as measured by years of schooling. And also the gap in education between spouses is the same in native partnerships and intermarriages. There are no statistically significant differences in natives' answers to the big five and risk proclivity questions. But intermarriages do not last as long as marriages between natives. With respect to social interaction, the likelihood of being friends with a non-German person is noticeably higher for men in intermarriage than for those in native marriages. Furthermore, native men in intermarriage are more likely to report having the final say on financial decisions than men in native relationships. This suggests more paternalistic gender roles in marriages between native men and immigrant women than within native couples, which goes in favor of a better bargaining position of the native wives compared to the immigrant wives.

There are no statistically relevant differences between intermarriage and native marriage for native women with regards to average working hours, the amount of time that their partners devote to labor market and household work or women's hours spend on household tasks. However, while average

\footnotetext{
${ }^{17}$ This corresponds to findings by Glowsky (2007) who studies marriage patterns of German men also using SOEP data.
} 
years of schooling in intermarriages and native marriages are almost identical, the difference in education is not. More precisely, while native women who live with a native men have about half a year less of education than the native partner, in intermarriage the educational gap between spouses is completely negligible. Again, intermarriages tend to end earlier than native partnerships. And as for native men, answers to the personality traits and risk attitudes do not differ, while the share of those reporting a best friend who does not come from West or East Germany is considerably higher among intermarried women than among those married to a native man. In addition, a higher percentage reports that each spouse manages his/her income separately in intermarriage than in partnerships between natives. Moreover, women are more likely to have the final say on financial decisions if they are intermarried.

For immigrants, differences by marriage type are considerably stronger. Accordingly, immigrant men in intermarriage work more hours per weekday than other immigrants. They devote about the same amount of hours to household tasks in intermarriage as in immigrant marriage, whereas the native wives spend more time working in the labor market and less time with household work than the immigrant wives. Furthermore, intermarried immigrant men have significantly more education than those in immigrant partnerships, and the difference in education between spouses is noticeably smaller and even insignificant in intermarriage. Moreover, those who live with natives have spent more years in the hosting country, immigrated at younger ages, report better linguistic abilities - both with respect to speaking and writing skills - and feel more attached to Germany and are more risk loving than immigrant men in marriages with other immigrants. In addition, intermarried immigrant men are more likely to report a best German friend, and they are, according to their self-assessment, more open and have higher values of extraversion than men in immigrant marriages - even though men in immigrant marriages view themselves as more agreeable. A noticeably higher percentage of immigrant men reports that each spouse manages his/her own money separately when they are intermarried. And, most strikingly, only 9.0 percent of immigrant men in intermarriage report to have the last word in financial decisions, in contrast to 16.6 percent of men in immigrant marriages.

Similar patterns evolve for immigrant women. Those intermarried provide more hours of labor market work than women in immigrant marriages. And also the native partners work more than the immigrant spouses. At the same time they spend less time on household tasks than women in immigrant partnerships. Immigrant wives with native husbands have considerably more years of education, although differences in education between partners are as big in intermarriages as in immigrant partnerships. As for men, intermarried immigrant women have spent more time in Germany, immigrated 
at younger ages, report better linguistic proficiency and a greater identification with Germany and less risk averse than women in immigrant marriages. Furthermore, they are more often friends with Germans and view themselves as more open and outgoing. 17.6 percent of immigrant women in intermarriage report that each spouse manages his/her own money separately, which contrasts to only 4.1 percent among women in immigrant marriages. Adding to that, 16.7 percent of women in immigrant partnerships report that the partner makes the final decisions on financial aspects, but only 11.5 percent of intermarried immigrant women make the same claim.

The descriptive findings imply that positive assortative matching by education is most severe in marriages between immigrant men and native women, and that bargaining strength of women - as proxied by self-reported power over financial decisions - is stronger in intermarriages than in immigrant marriages.

\section{$5 \quad$ Estimation Results}

\subsection{Two-limit Random Effects Tobit}

For the relevant years, 1,130 immigrant men in either intermarriage or immigrant partnerships are observed. For them the probability to live in a household where both partners work increases noticeably with intermarriage. The corresponding marginal effect on the probability that the index is smaller than one - recall that an index value of one refers to complete specialization of one spouse (mostly the husband) - is 0.13 and highly statistically significant (Table 3, Column 1). Even though own years of schooling appear insignificant for determining the division of labor, the probability to specialize rises with each additional year of schooling that the immigrant man achieved more than his wife. In addition, the probability to specialize increases with immigrant's age but not with the age gap between spouses. Interestingly, the probability to live in a partnership with two working partners increases in the duration of marriage. However, the magnitude is rather small and there is no change in the degree of specialization as an intermarriage persists because the two effects offset each other. Among the most prominent factors determining the division of labor in the household are children, as indicated by a highly significant increase in the probability to specialize if children under the age of 16 are present in the household. The same holds for Muslim immigrants. The chance to live in a fully specialized household rises noticeably if the immigrant reports to exhibit Islamic beliefs or to be Muslim. Estimates of language abilities which are measured on a scale from "very good skills" 
$(=1)$ to "very poor abilities" $(=5)$ indicate that those who report to have better German speaking proficiency (which corresponds to a smaller value of that variable) are more likely to live in dual working households. Speaking the home country language seems not significant for determining the division of labor for immigrant men. ${ }^{18}$

One of the short-comings of the specialization index is that it does not allow the unambiguous determination of who specializes in labor market work - the husband or the wife. To address this issue, the same regressions are run for immigrant men who contribute at least as many labor work hours as their wives. As a consequence, an increase in the index can unambiguously be interpreted as following more traditional gender roles in the sense that the husband is the single breadwinner and the wife concentrates on household tasks. Since the vast majority of cases (about 80 percent) refer to this category it is not surprising to find that this restriction does not change estimation results qualitatively - in contrast, the negative relationship between intermarriage and specialization becomes even more pronounced. ${ }^{19}$

The SOEP contains information for 1,188 immigrant women living in partnerships during the relevant years. For these women the likelihood to live in a fully specialized partnership also decreases in case of intermarriage (Table 4, Column 1). Hence, those who live with a native husband are more likely to live in a household where both spouses work. However, the relationship is smaller than for immigrant men and only significant at the 10 percent level. While educational attainment is insignificant, older immigrant women tend to live in more specialized relationships than younger ones supporting the assumption that younger generations adopt more egalitarian views with regard to female labor force participation. ${ }^{20}$ As for immigrant men, there seems to be no effect from additional years being intermarried, whereas marriage per se slightly increases the likelihood that both spouses work. Again, children living in the household as well as being Muslim or Islamic increases the probability of fully specialization drastically. Speaking the German language properly decreases this likelihood.

Between 1997 and 2005 a total of 5,874 native men are observed. Among them, intermarried native men are, in contrast to immigrants, more likely to live in fully specialized household when they are married to an immigrant wife (Table 5, Column 1). Accordingly, intermarriage increases the probability to completely specialize for native men. While more years of education lead

\footnotetext{
${ }^{18}$ Writing abilities are not included in the regression despite their availability in the SOEP because answers to speaking and writing skills are highly correlated and would induce multicollinearity.

${ }^{19}$ Estimation results are available upon request.

${ }^{20}$ This corresponds to arguments given by Fuwa (2004) for example.
} 
Table 3: Impact of Intermarriage on Specialization - for Immigrant Men

\begin{tabular}{|c|c|c|c|c|c|}
\hline $\begin{array}{l}\text { Dep. Var.: } \\
\text { Specialization Index }\end{array}$ & $\begin{array}{c}\text { RE }_{\text {Tobit }}{ }^{1} \\
(1)\end{array}$ & $\begin{array}{c}\text { Tobit }^{1} \\
(2)\end{array}$ & $\begin{array}{c}\text { Logit }^{1,2} \\
(3)\end{array}$ & $\begin{array}{c}\mathbf{L P M}^{3} \\
(4)\end{array}$ & $\begin{array}{c}\mathbf{I V}^{4} \\
(5) \\
\end{array}$ \\
\hline Intermarriage & $0.129^{* * *}$ & $0.130^{* * *}$ & $0.144^{* * *}$ & $0.144^{* * *}$ & $1.745^{* * *}$ \\
\hline Education & 0.006 & $0.011^{* *}$ & $0.027 * * *$ & $0.044^{* * *}$ & $0.026^{* *}$ \\
\hline More educ ${ }^{5} \times$ Difference in educ & $-0.023^{* * *}$ & $-0.026^{* * *}$ & $-0.039 * * *$ & $-0.050 * * *$ & $-0.031^{* *}$ \\
\hline Age & $-0.009 * * *$ & $-0.009 * * *$ & $-0.004^{*}$ & 0.002 & -0.009 \\
\hline Older $\times$ Difference in age & $0.007^{*}$ & $0.008^{* *}$ & 0.006 & 0.002 & $0.022 * *$ \\
\hline Duration of marriage & $0.005^{* *}$ & $0.006^{* * *}$ & 0.004 & -0.000 & $0.024^{* *}$ \\
\hline Duration of intermarriage & $-0.005^{*}$ & $-0.006^{* *}$ & $-0.007^{*}$ & $-0.007^{* *}$ & $-0.081 * * *$ \\
\hline Children younger than 16 & $-0.128^{* * *}$ & $-0.146^{* * *}$ & $-0.090^{* * *}$ & $-0.049^{* *}$ & 0.018 \\
\hline Being Muslim/Islamic & $-0.123^{* * *}$ & $-0.213^{* * *}$ & $-0.202^{* * *}$ & $-0.172^{* * *}$ & $-0.166^{* * *}$ \\
\hline Good German language skills & $-0.030^{* * *}$ & $-0.026^{* *}$ & $-0.029 * *$ & -0.013 & 0.045 \\
\hline Good skills in language of home country & -0.012 & $-0.028 * *$ & -0.014 & 0.007 & -0.027 \\
\hline \multicolumn{5}{|c|}{ Estimation coefficient of the IV on intermarriage variable in first stage: } & $-0.742^{* * *}$ \\
\hline
\end{tabular}

Source: German Socio-Economic Panel (SOEP), unbalanced panel, years 1997, 1999, 2001, 2003, 2005

Male immigrants aged 20 to 65 ; Comparison of those in intermarriage with those in immigrant marriages.

Clustered standard errors; ${ }^{*} p \leq 0.05,{ }^{* *} p \leq 0.01,{ }^{* * *} p \leq 0.001$

${ }^{1}$ Entries refer to marginal effects on the probability that both spouses work.

${ }^{2}$ Modified Dep. Var.: $=1$ if both spouses work, $=0$ if only one partner works.

${ }^{3}$ Entries refer to estimation coefficients using the same modified dep. Var. as in the logit regression

${ }^{4} I V=\frac{\text { number of opposite sex in the same ethnic group and the federal state }}{\text { total number of opposite sex in the federal state }}$

${ }^{5}$ Implying that this person has more years of schooling than his/her partner.

to less specialization, an increase in the educational gap between partners increases the incentive to divide tasks and thus increases the probability to specialize - as does an increase in men's age. As for immigrants, duration of marriage has no noticeable effect, whereas children seem to be crucial for a huge part of couple's division of labor.

Finally, the underlying data include observations for 6,047 married native women. Like for native men, intermarriage increases the probability to specialize compared to being married to a native man (Table 5, Column 2 ). In line with findings for the other subgroups, the probability to completely specialize is lower for better-educated women, although exhibiting more education than the spouse does not alter the division of labor. Similar to immigrant women, older native women tend to live in more specialized partnerships, whereas being older than the husband increases the probability that both partners work. This effect could be explained by arguing that in traditional families the husband is usually older than the wife. If the wife is older than the husband, this already expresses more modern perspectives which are reflected also in more modern views on female labor market participation and a more equal share of labor. Again, duration of marriage seems to play only a minor role for relative labor supply, whereas children determine 
Table 4: Impact of Intermarriage on Specialization - For Immigrant Women

\begin{tabular}{|c|c|c|c|c|c|}
\hline $\begin{array}{l}\text { Dep. Var.: } \\
\text { Specialization Index }\end{array}$ & RE $_{(1)}^{\text {Tobit }^{1}}$ & $\begin{array}{c}\text { Tobit }^{1} \\
(2)\end{array}$ & $\begin{array}{c}\text { Logit }^{1,2} \\
(3)\end{array}$ & $\begin{array}{c}\mathbf{L P M}^{3} \\
(4)\end{array}$ & $\begin{array}{c}\mathbf{I V}^{4} \\
(5)\end{array}$ \\
\hline Intermarriage & $0.084^{*}$ & 0.059 & $0.088^{*}$ & $0.094^{*}$ & $0.662^{*}$ \\
\hline Education & 0.005 & $0.008^{*}$ & $0.020 * * *$ & $0.037^{* * *}$ & $0.034^{* * *}$ \\
\hline More educ ${ }^{5} \times$ Difference in educ & 0.007 & 0.004 & -0.007 & $-0.018^{*}$ & -0.016 \\
\hline Age & $-0.007 * * *$ & $-0.005^{* *}$ & -0.000 & $0.006^{* *}$ & -0.001 \\
\hline Older $\times$ Difference in age & 0.005 & 0.008 & 0.003 & -0.003 & 0.002 \\
\hline Duration of marriage & $0.004^{* *}$ & $0.005^{* *}$ & 0.002 & -0.001 & 0.008 \\
\hline Duration of intermarriage & $-0.007^{* *}$ & $-0.008^{* * *}$ & $-0.009^{* *}$ & $-0.010^{* * *}$ & $-0.034^{* *}$ \\
\hline Children younger than 16 & $-0.150 * * *$ & $-0.151^{* * *}$ & $-0.103^{* * *}$ & $-0.063^{* *}$ & -0.042 \\
\hline Being Muslim/Islamic & $-0.079 * * *$ & $-0.150 * * *$ & $-0.141^{* * *}$ & $-0.109 * * *$ & $-0.076^{* *}$ \\
\hline Good German language skills & $-0.066^{* * *}$ & $-0.079 * * *$ & $-0.065^{* *}$ & $0.048^{* * *}$ & $0.043^{* * *}$ \\
\hline Good skills in language of home country & -0.008 & $-0.026^{* *}$ & -0.010 & 0.012 & 0.007 \\
\hline \multicolumn{5}{|l|}{ n coefficient of the IV on interr } & $-0.997^{* * *}$ \\
\hline
\end{tabular}

Source: German Socio-Economic Panel (SOEP), unbalanced panel, years 1997, 1999, 2001, 2003, 2005

Female immigrants aged 20 to 65 ; Comparison of those in intermarriage with those in immigrant marriages.

Clustered standard errors; ${ }^{*} p \leq 0.05,{ }^{* *} p \leq 0.01,{ }^{* * *} p \leq 0.001$

${ }^{1}$ Entries refer to marginal effects on the probability that both spouses work.

${ }^{2}$ Modified Dep. Var.: $=1$ if both spouses work, $=0$ if only one partner works.

${ }^{3}$ Entries refer to estimation coefficients using the same modified dep. Var. as in the logit regression

${ }^{4} I V=\frac{\text { number of opposite sex in the same ethnic group and the federal state }}{\text { total number of opposite sex in the federal state }}$

${ }^{5}$ Implying that this person has more years of schooling than his/her partner.

most of the couple's distribution of labor supply.

Summing up results from the two-limit random effects Tobit regressions, immigrant men are particularly more prone to more equal labor supply when intermarried than in marriages with immigrant women. This might be due to (a) greater assortative mating by education and hence less comparative advantages in the marriage, and (b) a better bargaining position of native wives compared to immigrant wives. Specialization also seems less frequent in marriages between immigrant women and native men than in partnerships between immigrant women and immigrant men. However, assortative mating is not so pronounced and the bargaining strength of the immigrant wives might also not be much different in the two types of partnerships.

In contrast, natives specialize more when intermarried than if in native marriages. Although this might contradict expectations at first sight, it might be explained by the fact that (a) native women are often married to immigrant men who come from mainly paternalistic countries such as Turkey and Italy. Hence, to mitigate conflict potential in the partnership those women might be willing to compromise on classical gender roles and thus accept a more traditional allocation of labor in the partnership; and (b) native men might specialize more when intermarried because of a weaker 
Table 5: Impact of Intermarriage on Specialization - Natives

\begin{tabular}{lcc}
\hline \hline Dep. Var.: & \multicolumn{2}{c}{ RE Tobit } \\
Specialization Index & $\begin{array}{c}\text { Men } \\
\text { Women } \\
(1)\end{array}$ & \multicolumn{1}{c}{$(2)$} \\
\hline Intermarriage & $-0.085^{* *}$ & $-0.075^{* *}$ \\
Education & $0.018^{* * *}$ & $0.019^{* * *}$ \\
More educ ${ }^{5} \times$ Difference in educ & $-0.022^{* * *}$ & -0.004 \\
Age & $-0.010^{* * *}$ & $-0.012^{* * *}$ \\
Older $\times$ Difference in age & 0.006 & $0.007^{* *}$ \\
Duration of marriage & 0.001 & $0.001^{*}$ \\
Duration of intermarriage & -0.001 & 0.002 \\
Children younger than 16 & $-0.152^{* * *}$ & $-0.152^{* * *}$ \\
\hline \hline Source: German Socio-Economic Panel $($ SOEP) & \\
Natives aged 20 to $65 ;$ Unbalanced panel, years $1997,1999,2001,2003,2005$ \\
Comparison of those in intermarriage with those in native marriages. \\
Clustered standard errors; ${ }^{*} p \leq 0.05,{ }^{* *} p \leq 0.01,{ }^{* * *} p \leq 0.001$ \\
${ }^{1}$ Entries refer to marginal effects on the probability that both spouses work. \\
${ }^{5}$ Implying that this person has more years of schooling than his/her partner.
\end{tabular}

bargaining position of immigrant wives compared to native wives.

\subsection{Alteration of Estimation Method}

One of the main flaws of the random effects models is that it does not allow the unobserved individual factors to correlate with the explanatory variables. Regarding the question addressed in this study, this is somewhat dissatisfying as intermarriage choice and the division of labor within the household may both be affected by unobserved factors such as ambitions, openness to new cultures and egalitarian views. As discussed in the data section, immigrants especially differ in their replies to, for example, the big five questions, depending on whether they are intermarried or live in immigrant partnerships. Hence, it can be expected that they exhibit different characteristics that might determine both partner choice and relative labor supply. Omitting such factors will then bias estimation results.

To address this endogeneity issue by using an instrumental variable approach, it is necessary to show that altering the functional form of the estimation model does not affect the empirical results. Tables 3 and 4 show that these transformations finally lead to the IV estimation. At first, instead of the panel Tobit model a simple cross-sectional Tobit is estimated using clustered standard errors to correct for dependences within individuals. As shown in Column 2 in each table this does not change results dramatically.

In a next step, a new binary variable is generated which equals one in 
case that both partners work, and zero in case of full specialization. Columns 3 show estimated marginal effects from Logit regressions using this modified specialization index as dependent variable. The entries report marginal effects on the probability to live in a dual worker partnership. Again, results are fairly stable and close to the Tobit results.

As argued by Angrist and Pischke (2008), functional form assumptions underlying the Logit regression can sometimes be ignored and a simple Linear Probability Model (LPM) will lead to the same results. This argument is supported by findings presented in Columns 4 showing that the Logit marginal effects are almost identical to the OLS estimates.

In a final step an IV estimation is proposed to account for the endogeneity problem. Thereby an instrument similar to that introduced by Meng and Gregory (2005) is used which takes into account that the probability to intermarry depends to a great amount on the availability of potential partners and hence the opportunity structure of the marriage market. The instrument used here is the ratio between the number of members of the opposite sex within the own ethnic groups in a certain region (in this case the federal state $^{21}$ ) and the total number of members of the opposite sex in that area. Hence, the smaller that ratio the less likely it is to meet a potential partner from the same ethnic group and the more likely it is to marry someone from outside the own ethnic community, in particular from the native population. As a consequence, a negative effect of that ratio on the probability to intermarry is expected.

As shown in the last row of Column 5, this negative relationship is indeed detected, as the corresponding estimation coefficients of the first stage regressions of the 2SLS estimations are negative and highly significant. Furthermore, the coefficients of the intermarriage indicators in the second stage are still significant at the same level as in the previous regressions and increased noticeably in size. Assuming that the ratio that serves as instrument is exogenous and not prone to endogeneity, this finding indicates that intermarriage indeed fosters more equal labor supply. The downward bias of the OLS estimate might thereby result from omitting important factors that affect both intermarriage choice and the degree of specialization. If, for instance, ambitions increase the probability to find a native partner but also increase the likelihood to be the main breadwinner in the family, the OLS will underestimate the effect of intermarriage on the probability to specialize if no adequate measure for ambitions is available.

\footnotetext{
${ }^{21}$ Ideally a closer regional frame would be preferred but this is not possible with the data used in this study. Further regional subdivision would reduce the sample size dramatically which would affect the explanatory power of the results.
} 
Unfortunately this instrument does not work for natives, as few theories exist that explain the driving factors for intermarriage. Trying to answer this question is beyond the scope of this paper but seems crucial for fully understanding the processes that determine intermarriage choice as a two-sided decision. But for now, since natives hardly respond differently depending on the origin of their partner, for example regarding their big five personality traits, omitted variable biases might not be as important for them as it is for immigrants.

\subsection{Robustness Checks}

One of the arguments made earlier about why intermarried couples might behave differently than ethnically homogeneous couples is that bargaining power is distributed differently - presumably more in favor of the native partner. A first indicator for that assumption was given in the descriptive section when two variables were discussed that measure who has the decision power over income and who has the final say in financial decisions. Such information can be used to proxy bargaining strength. ${ }^{22}$ Accordingly, intermarried immigrants are more likely to live in partnerships where financial decisions are made by both spouses.

To make this correlation more apparent, simple multinomial Logit regressions are run using those self-reported decision information as dependent variables and age and education as regressors (Table 6). This is a very simple specification which does not account for various problems related to, for instance, endogeneity or measurement errors. But for now the purpose is merely to visualize some correlations leaving aside causal relations.

Estimation results refer to marginal effects on the probability that a particular outcome is achieved. They indicate that for immigrant men intermarriage is highly correlated with more equal decision making within the couple. Interestingly, there seems to be no differences for natives and immigrant women. As already foreshadowed in the descriptive section, natives' behavior seems to be extensively independent of the origin of the spouse.

\section{Conclusion}

Social interactions are most obviously reflected in intermarriage patterns. Therefore, marriages between members of different groups are among the

\footnotetext{
${ }^{22}$ Variables similar to these are used by Lührmann and Maurer (2009), and Beegle et al. (2001) in order to measure bargaining power in the household.
} 
crucial factors fostering social and economic harmonization. By that, intermarriages serve as indicator of social proximity and are given credit for individual economic success of immigrants. However, little is known about the dynamics evolving within the couple, in particular regarding the division of labor between spouses. This paper therefore aims at filling part of that gap by analyzing relative labor supply of intermarried couples in comparison to immigrant and native couples.

The leading arguments that might explain differences in labor supply behavior, especially less specialization in intermarriage, are based on two issues: First, positive assortative matching by education, that is greater educational similarity of partners, is more pronounced in intermarriages than in other marital constellations leading to less comparative advantages and therefore less incentives to specialize. Second, bargaining positions of spouses might vary in intermarriages from that in immigrant or native marriages due to different outside options, different threat points and other factors determining bargaining strength.

As already hinted at in the descriptive statistics, the perceived bargaining position of native women in intermarriage is noticeably stronger than of women in immigrant partnerships. This impression is confirmed by results from a multinomial Logit regression. Accordingly, intermarried immigrant men are considerably more likely to decide in cooperation with their native wives when it comes to financial aspects and the distribution of income than immigrant men who live with immigrant women. However, no such difference depending on the origin of the partner is found in the data for natives and immigrant women. Furthermore, assortative mating is most pronounced in partnerships between native women and immigrant men, which lowers the incentives to specialize for those couples.

Results of a two-limit random effects Tobit model are also in line with the hypothesis stated above and regression estimated used to detect differences in relative labor supply indicate that intermarried immigrants live in less specialized partnerships than those in immigrant marriages. This result also holds when accounting for possible endogeneity of intermarriage in an instrumental variable approach. In contrast, natives in intermarriage are more specialized than those in native marriages possibly indicating less bargaining power of the immigrant wives and adaption in behavior of native women in intermarriages.

This analysis is only a first step on the way to a better understanding of what makes intermarried couples special and what drives their decisions. For further research it is of particular interest to detect what determines the decision to intermarry for natives if, for instance, immigrants are economically disadvantaged and intermarriages prone to more conflicts than ethni- 
cally homogeneous marriages. Moreover, differences in bargaining strength of spouses in different types of marriage should also be considered in greater detail.

With increasing globalization and higher mobility of people, it is crucial for multi-national and multi-cultural societies to better understand processes that encourage social proximity and acceptance of different cultural backgrounds. Intermarriages are in that context essential as they are the interface at which social interaction happens and people with different background actually intermingle. 


\section{References}

[1] Angrist, Joshua D. 2002. How do sex ratios affect marriage and labor markets? Evidence from America's second generation. The Quarterly Journal of Economics: 997-1038

[2] Angrist, Joshua D. and Jörn-Steffen Pischke. 2008. Mostly Harmless Econometrics: An Empiricist's Companion.

[3] Attanasio, Orazio and Valerie Lechene. 2002. Test of Income Pooling in Household Decisions. Review of Economic Dynamics Vol. 5: pp. 720-748

[4] Basilio, Leilanie, Bauer, Thomas K., and Mathias Sinning. 2009. Analyzing the labor market activity of immigrant families in Germany. Labour Economics Vol. 16: pp. 510-520

[5] Becker, Gary S. 1974. A Theory of Marriage. In: Economics of the Family: Marriage, Children, and Human Capital. Theodore W. Schultz (Ed.). Chicago: University of Chicago Press: pp. 299 - 351

[6] Becker, Gary S. 1981. A Treatise on the Family. Cambridge, Massachusetts and London, England: Harvard University Press

[7] Becker, Gary S. 1985. Human Capital, Effort, and the Sexual Division of Labor. Journal of Labor Economics Vol. 3, No. 1, Part 2: Trends in Women's Work, Education, and Family Building. pp. 33-58

[8] Beegle, Kathleen, Frankenberg, Elizabeth, and Duncan Thomas. 2001. Bargaining Power within Couples and Use of Prenatal and Delivery Care in Indonesia. Studies in Family Planing Vol. 32, No. 2.: pp. 130-146

[9] Bittmann, Michael, England, Paula, and Nancy Folbre. 2003. When Does Gender Trump Money? Bargaining and Time in Household Work. American Journal of Sociology Vol. 109, No. 1: pp. 186-214

[10] Blundell, Richard, Chiappori, Pierre-Andre, Magnac, Thierry, and Costas Meghir. 2007. Collective Labour Supply: Heterogeneity and NonParticipation.Review of Economic Studies Vol. 74: pp. 417-445

[11] Bonke, Jens, Deding, Mette, Lausten, Mette and Leslie S. Stratton. 2008. Intra-Household Specialization in Housework in the United States and Denmark. Social Science Quarterly Vol. 89, No. 4: pp. 1023-1043 
[12] Bratter, Jenifer L., and Karl Eschbach. 2005. 'What about the couple?' Interracial marriage and psychological distress. Social Science Research Vol. 35, Issue 4: pp. 1025-1047

[13] Chiappori, Pierre-Andre. 1988. Rational Household Labor Supply. Econometrica Vol. 56, No. 1: pp. 63-90.

[14] Chiappori, Pierre-Andre, Fortin, Bernard, and Guy Lacroix. 2002. Marriage Market, Divorce Legislation, and Household Labor Supply. The Journal of Political Economy Vol. 110, No. 1: pp. 37-72

[15] Chiswick, Barry R., and Christina A. Houseworth. 2008. Ethnic Intermarriage among Immigrants: Human Capital and Assortative Mating. IZA DP 3740

[16] Dehne, Max, and Juergen Schupp. 2007. Persoenlichkeitsmerkmale im Sozio-oekonomischen Panel (SOEP) - Konzept, Umsetzung und empirische Eigenschaften. DIW Research Notes 26

[17] Dribe, Martin and Christer Lundh. 2008. Intermarriage and Immigrant Integration in Sweden - An Exploratory Analysis. Acta Sociologica

[18] Furtado, Delia. 2006. Human Capital and Interethnic Marriage Decision. IZA DP 1989 (accepted: Economic Inquiry)

[19] Furtado, Delia, and Nikolaos Theodoropoulos. 2009a. I'll Marry You If You Get Me a Job: Marital Assimilation and Immigrant Employment Rates. International Journal of Manpower 30, Iss. 1/2: pp. 116 - 126

[20] Furtado, Delia, and Nikolaos Theodoropoulos. 2009b. Intermarriage and Immigrant Employment: The Role of Networks CReAM DP 06/09

[21] Furtado, Delia, and Nikolaos Theodoropoulos. 2010 (forthcoming). Interethnic Marriage: A Choice between Ethnic and Educational Similarities. Journal of Population Economics

[22] Fuwa, Makiko. 2004. Macro-Level Gender Inequality and the Division of Household Labor in 22 Countries. American Sociological Review Vol. 69, No. 6: pp. 751-767

[23] Georgarakos, Dimitris, and Konstantinos Tatsiramos. 2009. Immigrant Self-Employment. Does Intermarriage matter?. In: Prof. Solomon Polachek, Dr. Konstantinos Tatsiramos (Eds.), Ethnic and Labor Market Outcomes. Research in Labor Economics Vol. 29, Emerald Group Publishing Limited: pp. 253-271 
[24] Gevrek, Eylem. 2009. Interethnic Marriage and the Labor Market Integration of Immigrants. Job Market Paper

[25] Gerlitz, Jean-Yves, and Jürgen Schupp. 2005. Zur Erhebung der BigFive-basierten Persönlichkeitsmerkmale im SOEP. DIW Reseach Notes 4

[26] Glowsky, David. 2007. Why do German Men Marry Women from Less Developed Countries? An Analysis of Transnational Partner Search Based on the German Socio-Economic Panel. SOEP Papers on Multidisciplinary Panel Data Research 61

[27] Gonzalez-Ferrer, Amparo. 2006. Who do Immigrants Marry? Partner Choice Among Single Immigrants in Germany. European Sociological Review Vol. 22, No. 2: pp. 171-185

[28] Haug, Sonja. 2006. Interethnische Freundschaften, interethnische Partnerschaften und soziale Integration. Diskurs Kindheits- und Jugendforschung Heft 1: pp. 75-91

[29] Hersch, Joni, and Leslie S. Stratton.1994. Housework, Wages, and the Division of Housework Time for Employed Spouses. American Economic Review, Papers and Proceedings of the Hundred and Sixth Annual Meeting of the American Economic Association Vol. 84, No. 2: pp. 120-125

[30] Kalmijn, Matthijs, Graaf Paul M. de, and Jacques P. G. Janssen. 2005. Intermarriage and the risk of divorce $\mathrm{i}$ the Netherlands: The effects of differences in religion and in nationality, 1974-94. Population Studies Vol. 59, No. 1: pp. 71-85

[31] Kalter, Frank, and Nadia Granato. 2007. Educational Hurdles on the Way to Structural Assimilation in Germany. In: A.F. Heath and S. Yi Cheung (Eds.) Unequal Chances: Ethnic Minorities in Western Labour Markets Vol. 137, Proceedings of the British Academy by Oxford University Press, Oxford: pp. 269-317

[32] Kantarevic, Jasmin. 2004. Interethnic Marriages and Economic Assimilation of Immigrants. IZA DP 1142

[33] Klaveren, Chris van, Praag, Bernard van, and Henriette Maassen van den Brink. 2009. Collective Labor Supply of Native Dutch and Immigrant Household in the Netherlands. CESifo working paper No. 2872 
[34] Lührmann, Melanie and Jürgen Maurer. 2009. Who wears the trousers? A semiparametric analysis of decision power in couples. cemmap working paper CWP25/07

[35] Lundberg, Shelly, and Robert A. Pollak. 1996. Bargaining and Distribution in Marriage. The Journal of Economic Perspectives Vol. 10, No. 4: pp. $139-158$

[36] Meng, Xin, and Robert G. Gregory. 2005. Intermarriage and the Economic Assimilation of Immigrants. Journal of Labor Economics Vol. 23, No. 1: pp. 135-175

[37] Meng, Xin, and Dominique Meurs. 2009. Intermarriage, Language, and Economic Assimilation Process: A Case Study of France. International Journal of Manpower Vol. 30, Iss. 1/2: pp. 127 - 144

[38] Schroedter, Julia H. 2006. Binationale Ehen in Deutschland. Wirtschaft und Statistik 4/2006, Statistisches Bundesamt

[39] Stöcker-Zafari, Hiltrud. 2007. Lebenswirklichkeiten binationaler Paare. In: Eva ist emanzipiert, Mehmet ist ein Macho: Zuschreibung, Ausgrenzung, Lebensbewältigung und Handlungsansätze im Kontext von Migration und Geschlecht. Chantal Munsch, Marion Gemende, Steffi Weber-Unger Rotino (Eds.), Juventa Verlag

[40] Stratton, Leslie. 2005. Specialization in Household Activities within Cohabiting versus Married Households. Mimeo

[41] Wagner, Gert G., Joachim Frick, and Jürgen Schupp. 2007. The German Socio-Economic Panel Study (SOEP) - Scope, Evolution and Enhancements. Schmollers Jahrbuch Vol. 127, No. 1: pp. 139-169 